\title{
ACTIVATE SLUDGE TREATMENT OF LEACHATES FROM VÄÄTSA LANDFILL, ESTONIA
}

\author{
Mait Sooäär \\ Veemaailm INC, Estonia
}

\begin{abstract}
Väätsa Landfill is the first sanitary landfill in Estonia that meets the requirements of the EU landfill directive. The landfill is dimensioned to serve about 130000 inhabitants.

The first stage of landfill (out of seven) was accomplished in 2000. Disposal of wastes was started in November 2000. By now, the landfill contains: one hectare large disposal site for domestic waste, composting area for organic waste and storage site for construction wastes. In Estonia, the collection of recyclables has not jet developed. In Väätsa landfill, however, waste paper, glass and plastic are sorted. Organic waste is not separated on-site, and this is the reason why the organic content (nutritive waste) of garbage is high. Currently, the landfill serves approximately 40000 inhabitants.

According to the requirements of the client, Veemaailm INC designed and built a twophase activated sludge leachate treatment plant. First phase of the treatment, extended aeration, takes place in a container. In order to adjust the concentrations of biogenesis, Ortho Phosphorus Acid is added to the leachate. During the first phase, concentrations of pollutants are decreased approximately by $1 / 3$. The second phase of purification takes place in oxidation lagoon.

The leachate treatment plant worked effectively throughout the first year, both during the summer with high temperatures, and winter with low temperatures. During the first operating year, the main expenses were: energy for blowers, phosphorus acid for nutrient adjustment, and exchange oil for blowers. The analysis of the first operating year shows that BOD has decreased more than $95 \%$, COD approximately $90 \%$ and $\mathrm{N}$ on an average $60 \%$. The activated sludge process also reduced the concentrations of some heavy metals.
\end{abstract}

KEY WORDS: Technical solution, treatment efficiency 


\section{INTRODUCTION}

Väätsa Landfill was designed by the drafting department of PIC EESTI in 1998. Supervision of design was implemented by COWI, DENMARK. The constructor of the landfill was the MERKO construction company.

The first stage of the landfill construction ( $1 \mathrm{ha}$ ) was completed at the end of the year 2000. The landfill started storing waste in November 2000.

PIC Eesti did not design a leachates treatment plant for Väätsa Landfill. According to the design solution, leachates from the disposal site was collected by an underground drainage system to a pumping station. From the pumping station leachates was pumped to a collection lagoon with the volume of $2,500 \mathrm{~m}^{3}$. From the tank, trucks periodically freighted the leachates for treatment to Paide WTP. The distance between the landfill and Paide WTP is $15 \mathrm{~km}$.

In April 2002, a design and construction tender for Väätsa Landfill Leachate Treatment Plant was launched. Veemaailm INC was selected as the winning tenderer.

\section{BASIC DATA AND TERMS OF REFERENCE FOR DESIGN}

Table 1 Data of leachates from disposal area

\begin{tabular}{|l|l|l|l|}
\hline Constituent & Unit & Contsentration & Daily total \\
\hline Flowrate & & $7 \ldots 9$ & $30 \mathrm{~m}^{3} / \mathrm{d}$ \\
$\mathrm{pH}$ & & $7 \ldots .9$ & \\
$\mathrm{BOD}$ & $\mathrm{mgO}_{2} / \mathrm{l}$ & 3,000 & $90 \mathrm{~kg} / \mathrm{d}$ \\
$\mathrm{COD}$ & $\mathrm{mgO}_{2} / \mathrm{l}$ & 4,000 & $120 \mathrm{~kg} / \mathrm{d}$ \\
$\mathrm{SS}$ & $\mathrm{mg} / \mathrm{l}$ & 200 & $6 \mathrm{~kg} / \mathrm{d}$ \\
$\mathrm{P}_{\text {TOT }}$ & $\mathrm{mg} / \mathrm{l}$ & 1 & $0,3 \mathrm{~kg} / \mathrm{d}$ \\
$\mathrm{N}_{\text {TOT }}$ & $\mathrm{mg} / \mathrm{l}$ & 300 & $9 \mathrm{~kg} / \mathrm{d}$ \\
\hline
\end{tabular}

Pollution load $90 \mathrm{~kg} \mathrm{BOD}_{7} / \mathrm{d}$ responding to 1,500 population equivalents (PD).

\subsection{Requirements on LTP effluent}

In compliance with the Estonian legislation [1], an effluent of a landfill with the pollution load less than 2,000 population equivalents, must correspond to the following requirements 
KALMAR ECO-TECH'03

Bioremediation and Leachate Treatment

KALMAR, SWEDEN, November 25-27, 2003

Table 2 Effluent requirements

\begin{tabular}{|l|c|c|}
\hline \multicolumn{1}{|c|}{ Constituent } & $\begin{array}{c}\text { Marginal value of } \\
\text { pollution parameter } \\
\mathrm{mg} / \mathrm{l}\end{array}$ & $\begin{array}{c}\text { Or degree of purification } \\
\%\end{array}$ \\
\hline $\mathrm{BOD}_{7}$ & 15 & major/equal $90 \%$ \\
$\mathrm{COD}$ & 125 & major/equal $90 \%$ \\
$\mathrm{SS}$ & 25,0 & major/equal $80 \%$ \\
$\mathrm{P}_{\text {TOT }}$ in landfill effluent & 2,0 & major/equal $60 \%$ \\
$\mathrm{~N}_{\text {TOT }}$ in landfill effluent & Not applicable & Not applicable \\
\hline
\end{tabular}

\subsection{Additional requirements}

Additional requirements and conditions from the client were:

1. To select for leachates treatment a two-step activated sludge treatment where the first step is an activated sludge treatment in a prefabricated container plant and the second step in an oxidation lagoon.

2. The existing collection lagoon was to be utilised for constructing the oxidation lagoon.

3. Total cost of the turn key project had to be less than 1 million EEK $(64,000$ EUR)

4. For pumping stations, the existing pumping stations were to be utilised (except for the new underground pumping station, which pumps the partly treated leachates into the oxidation lagoon)

5. No expenditures and efforts were to be made to design and construct a nitrogen removal system.

6. The landfill is situated in a relatively cold climate zone. In the wintertime, the temperature of the leachates remains between +4 to $+78 \mathrm{C}$ for a long period. For technical calculations, the lowest air temperature was recommended $-35^{\circ} \mathrm{C}$.

\section{TECHNICAL SOLUTION}

From the existing wastewater pumping station, sewage pumps pump landfill leachates into a prefabricated container plant for an activated sludge treatment. An electromagnetic flowmeter MAGFLOß has been installed on the inlet pipe. For the optimisation of N:P ratio, a dosing pump adds Ortho Phosphoric Acid (1 1 contains $273 \mathrm{~g} \mathrm{P}$ ) to the container inlet.

The volume of the aeration tank (AT) is $70 \mathrm{~m}^{3} . \mathrm{O}_{2}$ concentration is retained at $0,8-1,5$ $\mathrm{mg} / \mathrm{l}$. On the bottom of AT, there are 42 PU diffusers AFD270 (from Stamford Scientific International, USA).

From AT the mixed liquid flows to a lamella separator (LS). 
KALMAR ECO-TECH'03

Bioremediation and Leachate Treatment

KALMAR, SWEDEN, November 25-27, 2003

A dry installation pump pumps the return sludge back to AT. The same pump pumps excess sludge to an excess sludge container. The excess sludge container is periodically depleted to disposal area.

From AT the partly treated leachates flows to the underground pumping station which pumps the partly treated leachates into the oxidation lagoon.

The existing collection tank were separated by bulkhead into two parts: oxidation lagoon and anoxic lagoon.

On the bottom of the oxidation lagoon there are 128 pcs Airflex PU tube diffusers $62 * 610$ $\mathrm{mm}$.

From the oxidation lagoon the mixed liquid flows into the anoxic lagoon and from the anoxic lagoon trough decanting overflow into a recipient stream.

The pressure pipeline from the pumping station to the oxidation lagoon inlet is supplied with electrical heating. Decanting overflow of the anoxic lagoon is also supplied with electrical heating.

In case of necessity, it is also possible to lead the treated effluent of anoxic tank for diluting raw leachates from the disposal site as a respective system has been built.

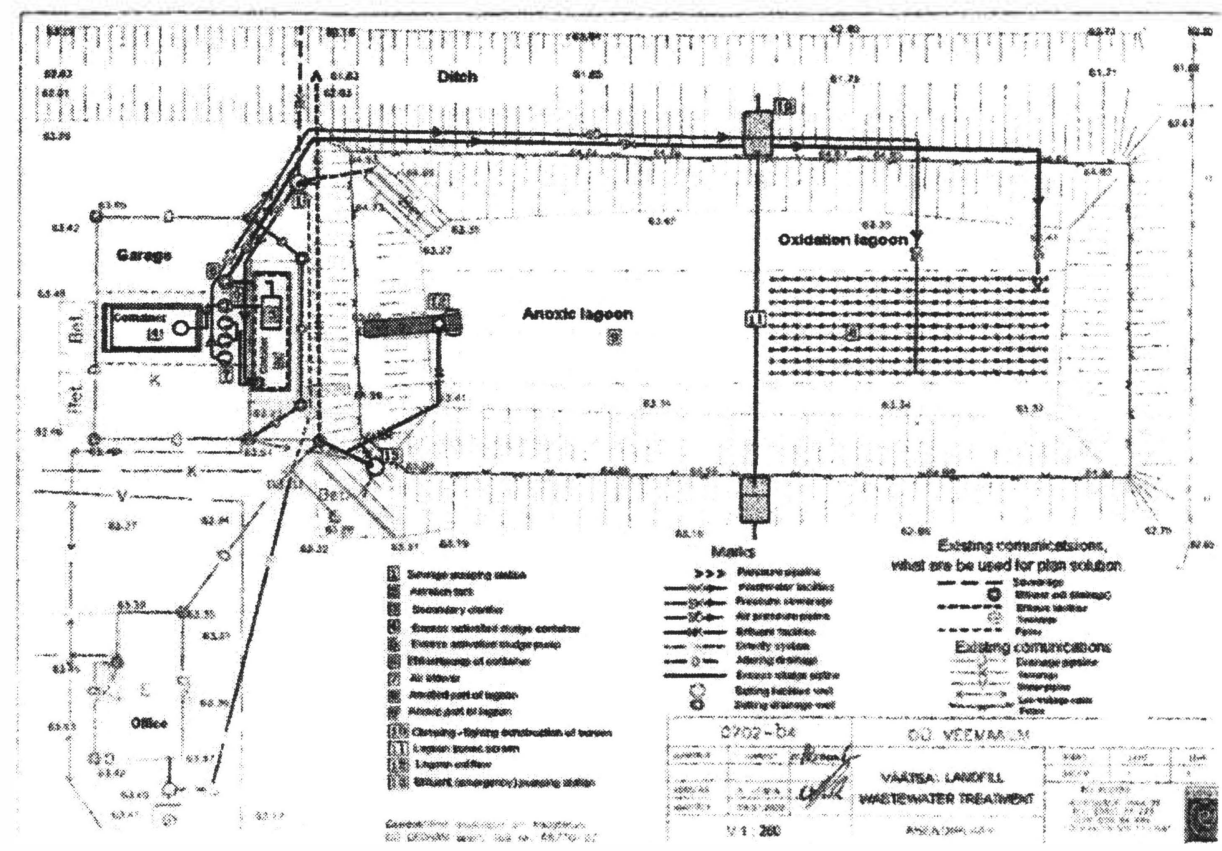

Figure 1 Situation plan of Väătsa Landfill Leachates Treatment Plant 


\section{ACTUAL FLOWRATE AND TREATMENT EFFICIENCY}

Plant started under operation in October 2002.

Table 3 Actual flow rate of leachates

\begin{tabular}{|l|c|c|c|}
\hline \multicolumn{1}{|c|}{$\begin{array}{c}\text { Month, } \\
\text { year }\end{array}$} & $\begin{array}{c}\text { Overage daily } \\
\text { flow rate } \mathrm{m}^{3} / \mathrm{d}\end{array}$ & $\begin{array}{c}\text { Minimum day } \\
\text { flow rate } \mathrm{m}^{3} / \mathrm{d}\end{array}$ & $\begin{array}{c}\text { Maximum day } \\
\text { flow rate } \mathrm{m}^{3} / \mathrm{d}\end{array}$ \\
\hline November 2002 & 17,2 & 12,4 & 24,7 \\
December 2002 & 8,5 & 2 & 27,0 \\
January 2003 & 10,7 & 5 & 30,6 \\
February 2003 & 3,2 & 1 & 7,0 \\
March 2003 & 17,8 & 2 & 84,0 \\
April 2003 & 12,7 & 5 & 35,0 \\
May 2003 & 12,0 & 7 & 29,0 \\
June 2003 & 5,9 & 4 & 11,0 \\
July 2003 & 11,3 & 3 & 80,0 \\
August 2003 & 10,5 & 5 & 23,0 \\
September 2003 & 6,8 & 1 & 16,0 \\
October 2003 & 10,7 & 6 & 19,0 \\
\hline Year & 10,25 & 1 & 84,0 \\
\hline
\end{tabular}

\subsection{Constituent concentrations of leachates from disposal area}

Table 4. Leachates constituent concentrations

\begin{tabular}{|l|c|c|c|c|c|c|c|c|}
\hline Month & $\begin{array}{c}\mathrm{BOD}_{7} \\
\mathrm{mgO}_{2} / 1\end{array}$ & $\begin{array}{c}\mathrm{COD} \\
\mathrm{mgO}_{2} / 1\end{array}$ & $\mathrm{pH}$ & $\begin{array}{c}\mathrm{P}_{\mathrm{TOT}} \\
\mathrm{mg} / \mathrm{l}\end{array}$ & $\begin{array}{c}\mathrm{N}_{\mathrm{TOT}} \\
\mathrm{mg} / \mathrm{l}\end{array}$ & $\begin{array}{c}\mathrm{NO}_{3}{ }^{-} \\
\mathrm{mgN} / \mathrm{l}\end{array}$ & $\begin{array}{c}\mathrm{SO}_{4}{ }^{2-} \\
\mathrm{mg} / \mathrm{l}\end{array}$ & $\begin{array}{c}\mathrm{SS} \\
\mathrm{mg} / \mathrm{l}\end{array}$ \\
\hline November & 371 & 111 & 8,0 & 3,8 & 236,2 & & & 708 \\
December & 3,576 & 8,130 & 7,19 & 1,64 & 410,8 & & 205 & 253 \\
March & 1,650 & 2,700 & 7,0 & 0,76 & 171 & 8,0 & 210 & \\
May & 2,000 & 6,000 & 7,05 & 1,8 & 397 & 0,05 & 51 & \\
June & 5,300 & 6,900 & 7,25 & 2,7 & 518 & 0,03 & 2,4 & \\
13.August & 2,645 & 4,240 & 7,56 & 1,4 & 445 & 7,5 & & \\
15.August & 2,385 & 4,340 & 7,52 & 1,4 & 468 & 7,5 & & \\
17.August & 1,760 & 3,900 & 7,44 & 1,1 & 416 & 7,5 & & \\
19.August & 1,530 & 3,740 & 7,48 & 1,4 & 434 & 2 & & \\
26.August & 1,850 & 3,475 & 7,48 & 1,08 & 482 & 5 & & \\
02.September & 1,550 & 3,157 & 7,49 & 1,5 & 436 & 5 & & \\
11.September & 1,700 & 2,900 & 7,55 & 2,0 & 400 & 0,05 & & \\
\hline
\end{tabular}


KALMAR ECO-TECH'03

Bioremediation and Leachate Treatment

KALMAR, SWEDEN, November 25-27, 2003

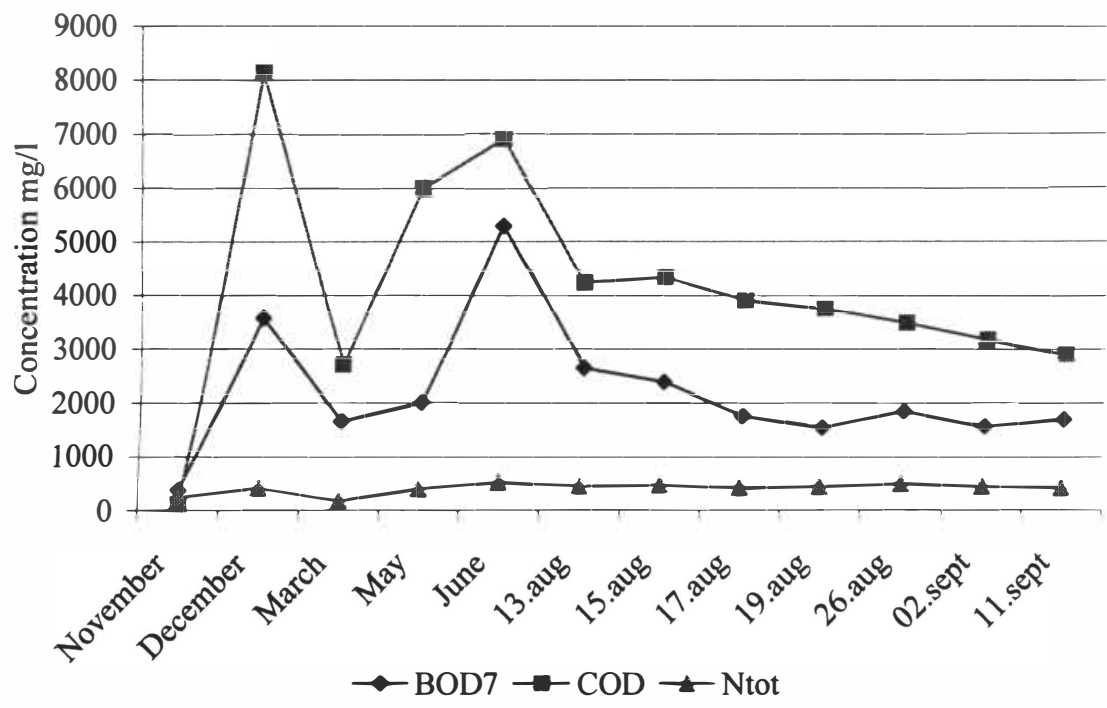

Figure 2. $\mathrm{BOD}_{7}, \mathrm{COD}$ and $\mathrm{N}_{\mathrm{TOT}}$ dependence of date in inlet

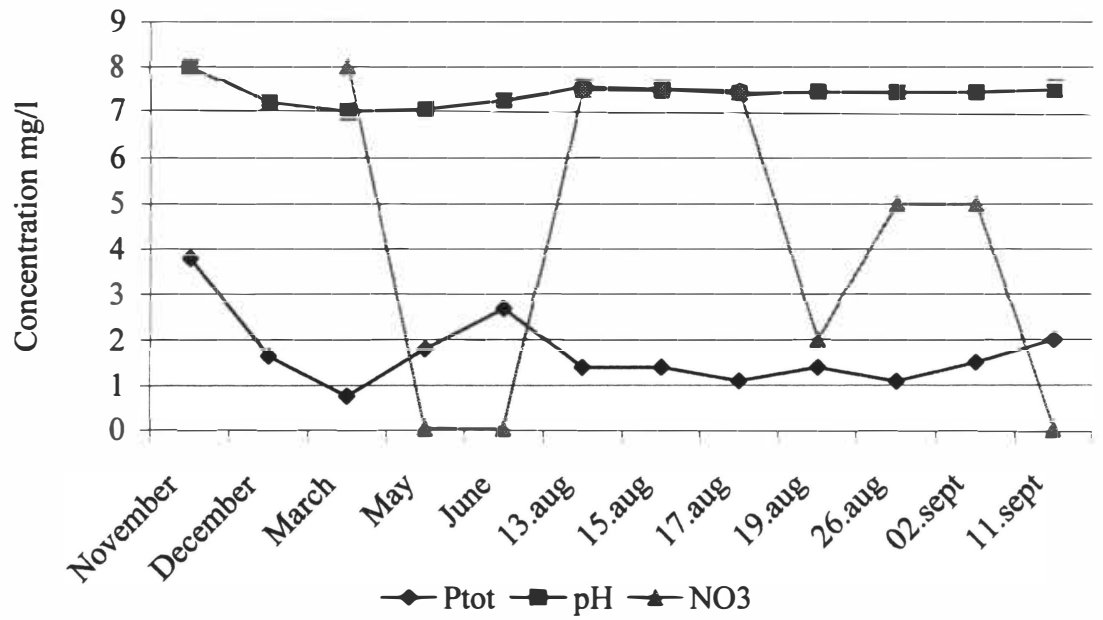

Figure 3. $\mathrm{P}_{\text {TOT }}, \mathrm{pH}$ and $\mathrm{NO}_{3}{ }^{-}$dependence of date in leachate 
KALMAR ECO-TECH'03

Bioremediation and Leachate Treatment

KALMAR, SWEDEN, November 25-27, 2003

\subsection{Efluent constituent concentrations}

Table 5. Effluent constituent concentrations

\begin{tabular}{|l|c|c|c|c|c|c|c|c|}
\hline Month & $\begin{array}{c}\mathrm{BOD}_{7} \\
\mathrm{mgO}_{2} / 1\end{array}$ & $\begin{array}{c}\mathrm{COD} \\
\mathrm{mgO}_{2} / 1\end{array}$ & $\mathrm{pH}$ & $\begin{array}{c}\mathrm{P}_{\mathrm{TOT}} \\
\mathrm{mg} /\end{array}$ & $\begin{array}{c}\mathrm{N}_{\mathrm{TO}} \\
\mathrm{mg} /\end{array}$ & $\begin{array}{c}\mathrm{NO}_{3}{ }^{-} \\
\mathrm{mgN} / 1\end{array}$ & $\begin{array}{c}\mathrm{SO}_{4}{ }^{2-} \\
\mathrm{mg} /\end{array}$ & $\begin{array}{c}\mathrm{SS} \\
\mathrm{mg} / 1\end{array}$ \\
\hline November & 19,8 & 111 & 7,93 & 22,74 & 165,8 & & & 42 \\
December & 58,5 & 370 & 8,15 & 5,62 & 99 & 4,9 & 295 & 60 \\
March & 60 & 500 & 8,7 & 1,3 & 145 & 4,1 & 174 & \\
May & 50 & 420 & 8,65 & 1,8 & 131 & $<0,02$ & 98 & \\
June & 62 & 430 & 8,85 & 2,9 & 115 & 0,1 & 70 & \\
13.August & 55 & 567 & 8,91 & 1,4 & 84 & 25 & & \\
15.August & 51 & 535 & 8,65 & 1,0 & 105 & 22,5 & & \\
17.August & 77 & 547 & 8,79 & 1,4 & 102 & 22,5 & & \\
19.August & 36 & 556 & 8,85 & 1,2 & 105 & 20 & & \\
26.August & 30 & 446 & 8,76 & 1,2 & 147 & 11 & & \\
02.September & 75 & 474 & 8,78 & 1,1 & 130 & 9 & & \\
11.September & 52 & 450 & 8,9 & 1,2 & 75 & 6,0 & 51 & \\
\hline
\end{tabular}

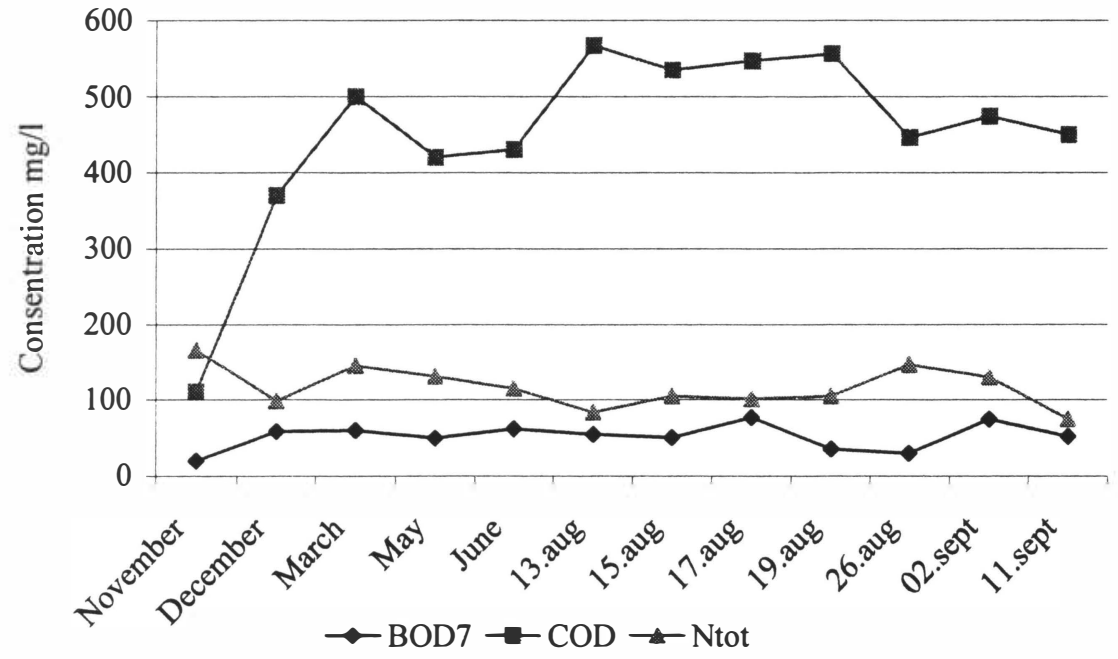

Figure 4. $\mathrm{BOD}_{7}, \mathrm{COD}$ and $\mathrm{N}_{\mathrm{TOT}}$ dependence of date in effluent 
KALMAR ECO-TECH'03

Bioremediation and Leachate Treatment

KALMAR, SWEDEN, November 25-27, 2003

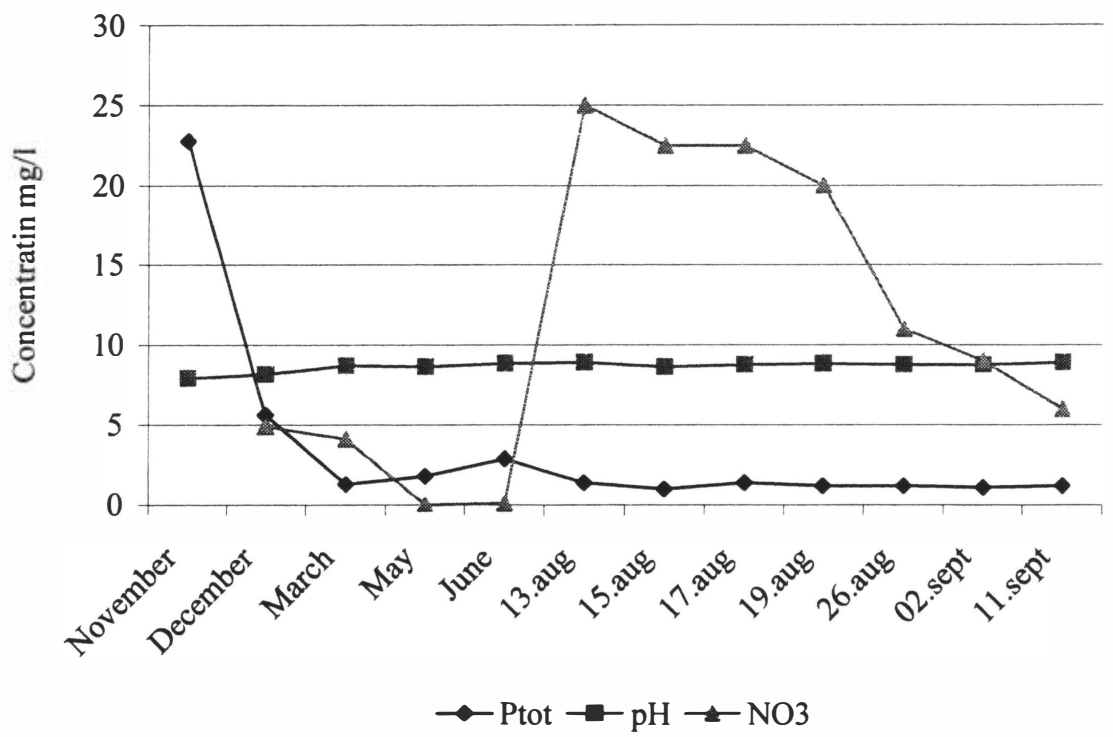

Figure 5. $\mathrm{P}_{\text {TOT, }} \mathrm{pH}$ and $\mathrm{NO}_{3}{ }^{-}$dependence of date in effluent.

\section{BOD, COD AND N EFFICIENCY}

Table 6. Treatment efficiency

\begin{tabular}{|l|c|c|c|}
\hline Month & $\begin{array}{c}\mathrm{BOD}_{7} \\
\%\end{array}$ & $\begin{array}{c}\text { COD } \\
\%\end{array}$ & $\begin{array}{c}\mathrm{N}_{\text {TOT }} \\
\%\end{array}$ \\
\hline Nonstituent & & & \\
Necember & 94,7 & - & 29,8 \\
March & 98,4 & 95,4 & 75,9 \\
May & 96,4 & 81,5 & 15,2 \\
June & 97,5 & 93,0 & 67 \\
August & 98,8 & 93,8 & 77,8 \\
September & 97,5 & 86,5 & 75,8 \\
\hline Average & 96,0 & 84,7 & 75,4 \\
\hline
\end{tabular}


KALMAR ECO-TECH'03

Bioremediation and Leachate Treatment

KALMAR, SWEDEN, November 25-27, 2003

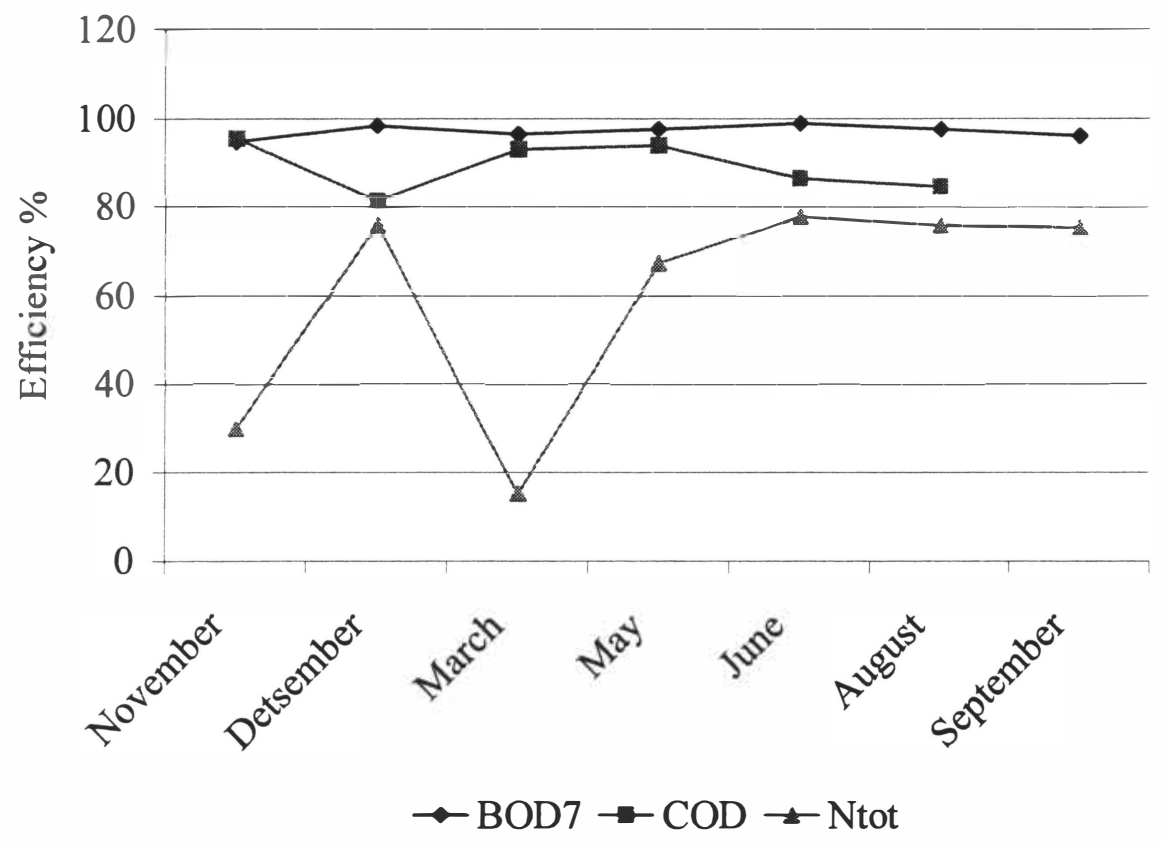

Figure 6. $\mathrm{BOD}_{7}, \mathrm{COD}$ and $\mathrm{N}_{\mathrm{TOT}}$ treatment efficiency dependence of month

\subsection{Concentrations of heavy metals in Väätsa Landfill leachates and effluent}

Table 7. Concentrations of heavy metals in Väätsa Prügila leachates and effluent

\begin{tabular}{|l|c|c|c|c|c|c|c|c|}
\hline & \multirow{2}{*}{ Constituent } & Unit & \multicolumn{2}{|c|}{$\begin{array}{c}\text { Before plant } \\
\text { operation }\end{array}$} & $\begin{array}{c}\text { Before } \\
\text { treatment }\end{array}$ & \multicolumn{2}{|c|}{ After treatment plant } & Standard \\
\cline { 3 - 9 } & & 17.0 d.02 & 17.05 .02 & 26.11 .02 & 26.11 .02 & 18.03 .03 & 19.06 .03 & \\
\hline Cadmium $(\mathrm{Cd})$ & $\mu \mathrm{g} / \mathrm{l}$ & $<0,1$ & 0,3 & 0,4 & 0.1 & $<0,1$ & $<0,1$ & 0,2 \\
Chromium(Cr) & $\mathrm{mg} / 1$ & 0,035 & 0,144 & 0,099 & 0,016 & 0,026 & 0,026 & 0,5 \\
Copper $(\mathrm{Cu})$ & $\mathrm{mg} / 1$ & $<0,04$ & 0,047 & $<0,04$ & $<0,04$ & $<0,05$ & $<0,04$ & 2 \\
Mercury $(\mathrm{Hg})$ & $\mu \mathrm{g} / \mathrm{l}$ & $<0,05$ & $<0,05$ & 0,1 & $<0,05$ & 0,022 & $<0,05$ & 0,05 \\
Nickel $(\mathrm{Ni})$ & $\mathrm{mg} / 1$ & 0,015 & 0,148 & 0,096 & 0,016 & 0,006 & 0,024 & 1 \\
Lead $(\mathrm{Pb})$ & $\mathrm{mg} / 1$ & 0,01 & 0,01 & 0,009 & 0,004 & 0,022 & 0,001 & 0,5 \\
Zinc $(\mathrm{Zn})$ & $\mathrm{mg} / 1$ & 0,03 & 0,077 & 0,121 & 0,012 & 0,04 & 0,01 & 2 \\
\hline
\end{tabular}

NB Storage of wastes started in November of 2000. Leachates treatment started in October of 2002. 


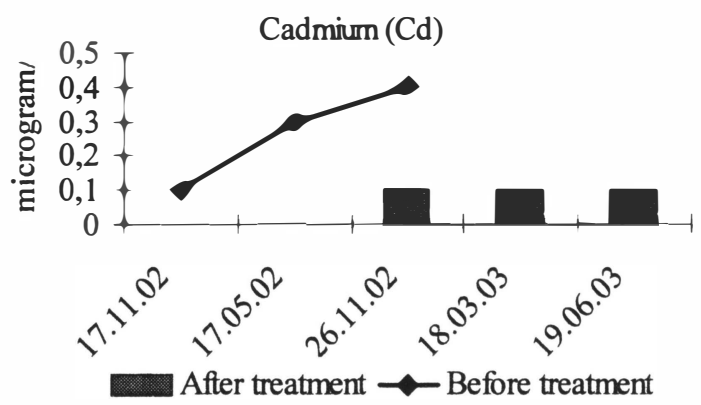

Figure 7.1. Cadmium (Cd)

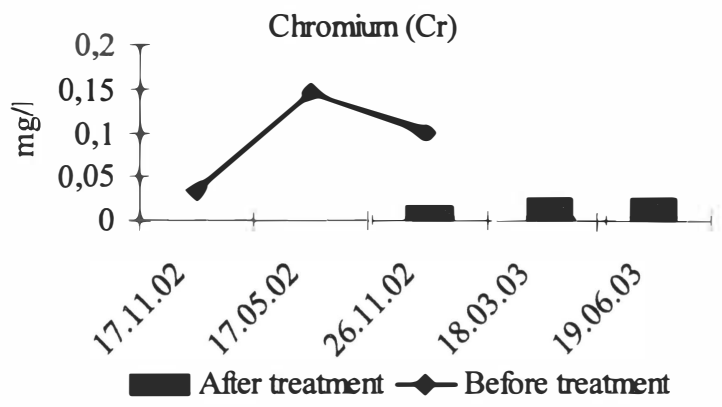

Figure 7.2. Chromium (Cr)

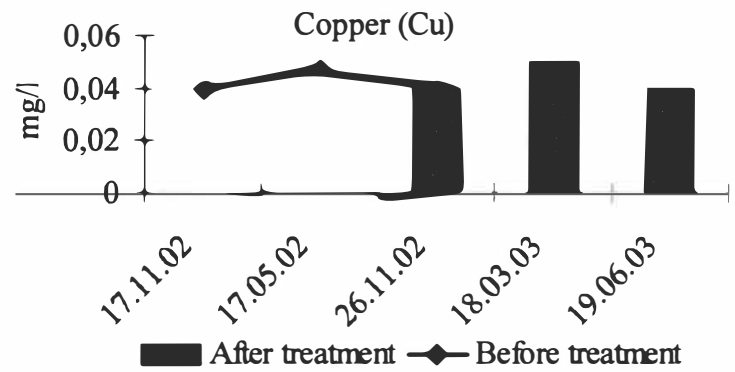

Figure 7.3. Copper $(\mathrm{Cu})$ 


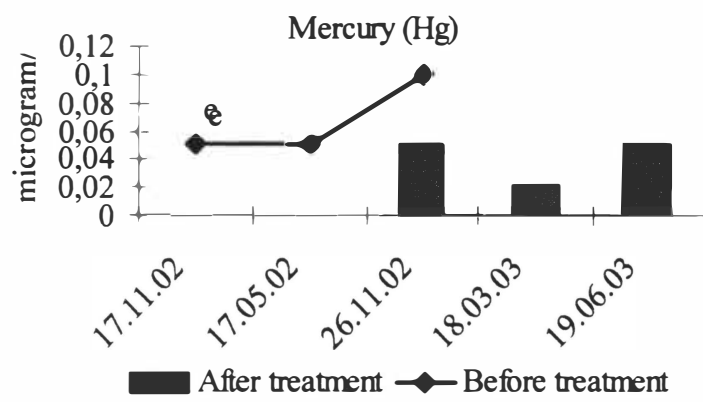

Figure 7.4. Mercury (Hg)

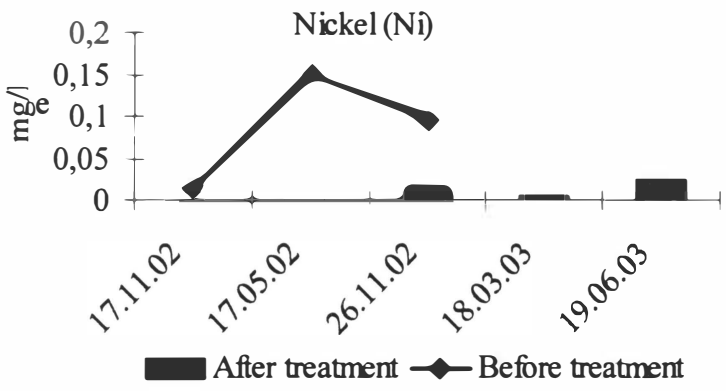

Figure 7.5 Nickel (Ni)

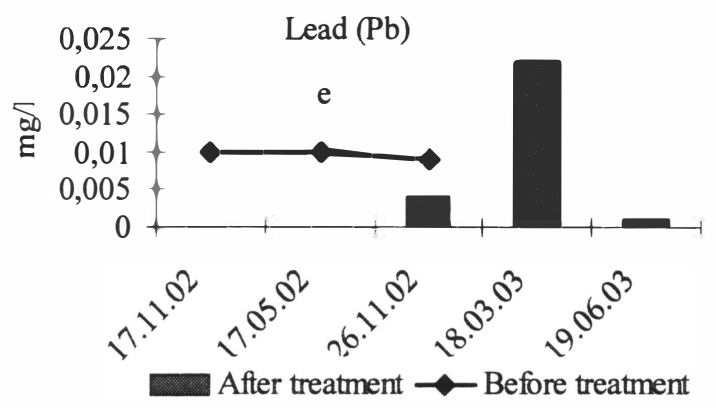

Figure 7.6. Lead $(P b)$ 


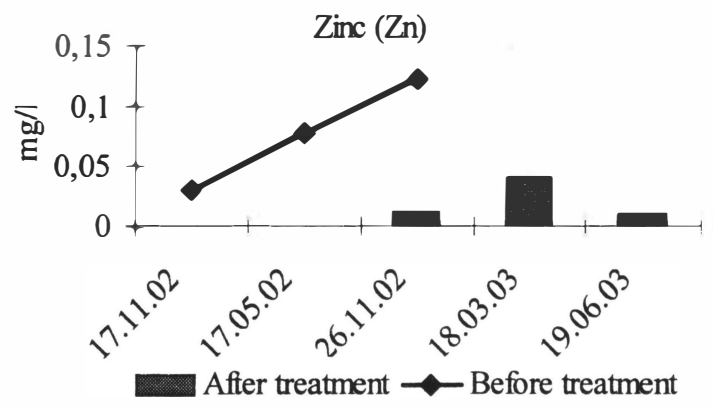

Figure 7.7. Zinc (Zn)

\section{REFERENCES}

[1] Vabariigi Valitsuse 31.juuli 2001a. määrus nr 269 "Heitvee veekogusse või pinnasesse juhtimise kord" RTI 2001, 69, 424 